\title{
Mitigasi Alami Pengasaman Laut
}

\author{
Mochammad Rafli Noer Haiqal ${ }^{1 *}$, Balqis Wahyu Utami ${ }^{1}$, Luthfiah Achmad ${ }^{1}$, \\ Ade Suryanda ${ }^{1}$ \\ ${ }^{1}$ Universitas Negeri Jakarta, Jl. Rawamangun Muka, RT.11/RW.14, Rawamangun, Pulo Gadung, \\ Kota Jakarta Timur, Daerah Khusus Ibukota Jakarta 13220
}

\section{Kata Kunci:}

pengasaman laut, mitigasi, lamun, bakau, alga

\begin{abstract}
Abstrak
Peningkatan karbon dioksida $\left(\mathrm{CO}_{2}\right)$ yang ada di atmosfer telah menggangu keadaan laut dengan meningkatkan keasamannya sebesar $30 \%$. Secara global, $\mathrm{pH}$ lautan telah turun dari 8,2 ke 8,1, dan bisa turun 0,4 unit lagi pada akhir abad ini. Apabila produksi $\mathrm{CO}_{2}$ yang berlebih terus terjadi, tidak menutup kemungkinan keadaan laut akan semakin memburuk. Tumbuhan di lautan, seperti lamun dan bakau hingga alga dapat menjadi solusi untuk meningkatkan $\mathrm{pH}$ lautan. Untuk mengetahui seberapa besar pengaruh komponen tersebut, artikel ini bertujuan untuk mensintesis pengetahuan yang tersedia dalam tinjauan global mengenai peranan lamun, bakau, dan alga. Penelitian ini dilakukan menggunakan metode studi literatur dengan mengkaji beberapa artikel terkait. Kami menemukan bahwa lamun mangrove dan alga dapat meningkatkan kemampuan laut untuk mengembalikan keadaan $\mathrm{pH}$ kembali normal. Sehingga, lamun, mangrove, dan alga dapat mengurangi tingkat keasaman laut.
\end{abstract}

\section{Keywords:}

ocean acidification, mitigation, seagrasses, mangroves, algae

\section{Abstract}

The increase in carbon dioxide $\left(\mathrm{CO}_{2}\right)$ in the atmosphere has disturbed the state of the ocean by increasing its acidity by $30 \%$. Globally, the $\mathrm{pH}$ of the oceans has fallen from 8.2 to 8.1, and could drop 0.4 units again by the end of this century. If the excess of $\mathrm{CO}_{2}$ production continues to occur, it is possible for the sea to worsen. Plants in the ocean, such as seagrasses and mangroves to algae can be a solution to increase the $\mathrm{pH}$ of the ocean. To find out how much influence these components have, this article aim to synthesize the knowledge available in a global review of the role of seagrass, mangroves, and algae. This research was conducted using the literature study method by examining several related articles. We found that mangrove seagrasses and algae can increase the ability of the ocean to return the $\mathrm{pH}$ back to normal. So that seagrasses, mangroves, and algae can reduce the acidity of the sea.

\footnotetext{
* Penulis koresponden: mraflinoerhaiqal 1304617044@mhs.unj.ac.id
} 


\section{PENDAHULUAN}

Peningkatan emisi gas rumah kaca menjadi isu lingkungan serius yang terjadi di seluruh dunia. Hampir semua negara berperan dalam menyumbangkan emisi gas rumah kaca ke atmosfer. Benua Asia menjadi penyumbang terbanyak akan emisi gas global, yaitu sekitar $53 \%$, Benua Amerika $18 \%$, dan Benua Eropa $17 \%$ (Le Quéré et al. 2018). Gas rumah kaca sejatinya merupakan gas yang tercipta secara alami namun juga dapat diciptakan akibat aktivitas manusia seperti pembakaran bahan bakar fosil, pembakaran hutan, polusi limbah pabrik yang tidak terolah dengan baik, aktivitas pertanian, dan masih banyak contoh lainnya yang menjadi penyebab utama terjadinya peningkatan emisi gas rumah kaca.

Gas rumah kaca diartikan sebagai gas yang terkandung dalam atmosfer Bumi yang memiliki kemampuan menyerap dan memantulkan gelombang radiasi infra merah dari matahari (Martono 2012). Tanpa gas rumah kaca pada atmosfer, bumi akan menjadi dingin dan menjadi tidak bisa ditempati oleh manusia. Gas rumah kaca berfungsi seperti kaca pada rumah kaca yaitu memungkinkan cahaya matahari masuk ke dalam bumi, sehingga bumi menjadi hangat dan nantinya sebagian sinar matahari yang masuk dapat dipantulkan kembali ke atmosfer dalam bentuk radiasi sinar infra merah. Beberapa contoh gas rumah kaca tersebut ialah $\mathrm{CO}_{2}, \mathrm{CH}_{4}, \mathrm{~N}_{2} \mathrm{O}$, HFCs, PFCs, $\mathrm{SF}_{6}, \mathrm{CF}_{3} \mathrm{I}, \mathrm{CH}_{2} \mathrm{Br}_{2}, \mathrm{CHCl}_{3}$, $\mathrm{CH}_{3} \mathrm{Cl}$, dan $\mathrm{CH}_{2} \mathrm{Cl}_{2}$ (Martono 2012).

Gas karbon dioksida $\left(\mathrm{CO}_{2}\right)$, metana $\left(\mathrm{CH}_{4}\right)$ dan nitrogen dioksida $\left(\mathrm{N}_{2} \mathrm{O}\right)$ merupakan gas yang terkandung paling banyak di atmosfer. Pada tahun 2017, konsentrasi $\mathrm{CO}_{2}$ di atmosfer mencapai 405,5 ppm dan terus meningkat 100 persen setiap tahunnya. Urutan kedua yaitu $\mathrm{CH}_{4}$ dengan konsentrasi sekitar 1,859 ppm dan $\mathrm{NO}_{2}$ mencapai 0,3299 ppm dan akan terus meningkat (World Meteorological Organization 2018). Kadar gas rumah kaca yang terlalu banyak dapat berpengaruh buruk bagi bumi, seperti panas matahari akan lebih banyak yang terserap dibandingkan yang dipantulkan. Akibatnya, temperature bumi akan meningkat dan terjadilah pemanasan global.

Pemanasan global dapat dikurangi dengan cara menyerap sebagian emisi gas rumah kaca ke dalam laut. Salah satu gas rumah kaca yang diserap oleh laut ialah $\mathrm{CO}_{2}$. Gas $\mathrm{CO}_{2}$ yang terserap ke laut akan bereaksi dengan molekul air dan menciptakan asam karbonat $\left(\mathrm{H}_{2} \mathrm{CO}_{3}\right)$. Asam karbonat ini nantinya akan menjadi bikarbonat dan ion hidrogen bebas.

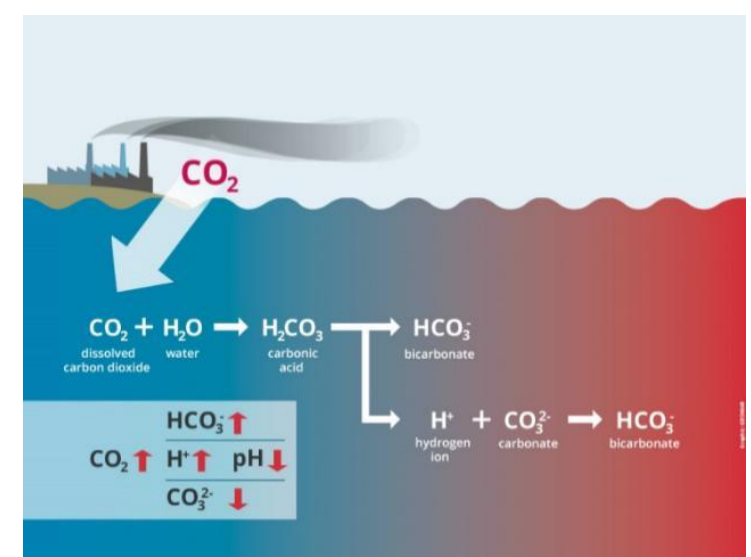

Gambar 1. Pengasaman laut ("Biological Impact of Ocean Acidification," n.d.)

Akan tetapi, karena kadar $\mathrm{CO}_{2}$ di atmosfer tidak kunjung berkurang, maka akibat yang dapat timbul ialah laut mencapai kapasitas maksimalnya dalam menampung $\mathrm{CO}_{2}$. Kelebihan $\mathrm{CO}_{2}$ di laut akan memicu terjadinya pengasaman laut. Pengasaman laut terjadi karena $\mathrm{pH}$ air laut mengalami penurunan akibat peningkatan kadar $\mathrm{CO}_{2}$ terlarut di laut. Ion Hidrogen yang terbentuk dari pemecahan asam karbonat akan menyebabkan $\mathrm{pH}$ cenderung asam. Meningkatnya kadar $\mathrm{CO}_{2}$ yang masuk ke laut menyebabkan ion $\mathrm{H}$ yang terbentuk menjadi lebih banyak dan akhirnya terjadilah pengasaman laut.

Pengasaman laut akan berpengaruh buruk terhadap laut, khususnya para penghuni laut. Salah satunya ialah berpengaruh terhadap keberlangsungan ekosistem terumbu karang. Terumbu karang merupakan hewan yang sensitif terhadap perubahan lingkungan. Perubahan seperti suhu dan $\mathrm{pH}$ yang diakibatkan oleh pengasaman laut dapat menyebabkan hilangnya alga yang berasosiasi dengan karang dan menyebabkan karang mengalami pemutihan atau Bleaching (Pandolfi dkk. 2011). Pemutihan karang dapat berpengaruh pada hidup karang karena dengan hilangnya alga yang berasosiasi dengan karang, maka karang akan kekurangan nutrisi dan jika terus berlangsung akan mempengaruhi keadaan ekosistem terumbu karang. Ikan-ikan pun akan meninggalkan terumbu karang tersebut dan memberi efek ke rantai makanan. Sehingga dapat dikatakan bahwa dari adanya pemutihan 
karang akan menjadi masalah yang kompleks karena dapat mengganggu rantai makanan biota laut.

Selain itu, pengasaman laut yang diakibatkan peningkatan $\mathrm{CO}_{2}$ akan membuat kadar ion karbonat $\left(\mathrm{CO}_{3}^{-}\right)$menipis karena terus berikatan dengan ion hidrogen $\left(\mathrm{H}^{+}\right)$yang sangat reaktif. Hal inilah yang akan menghambat proses kalsifikasi dari karang dan moluska karena kekurangan asupan ion karbonat. Hal ini akan mengakibatkan semakin kecilnya ukuran tubuh moluska tersebut dan bahkan akan mempengaruhi jumlah populasi dari moluska dan berdampak pada terbentuknya karang tersebut.

Apabila produksi $\mathrm{CO}_{2}$ yang berlebih terus terjadi, tidak menutup kemungkinan keadaan laut akan semakin memburuk hari demi hari. Laut akan berada di ambang kerusakan dan hewan-hewan penghuni laut akan mengalami ancaman kepunahan. Kerusakan laut dan kepunahan beberapa hewan di laut tentunya akan berdampak kepada manusia. Hilangnya fungsi laut sebagai penyerap panas, hilangnya fungsi laut sebagai sumber pasokan oksigen terbesar di bumi, hilangnya sumber protein terbesar untuk manusia, dan masih banyak dampak negatif yang dapat muncul dari kerusakan yang terjadi.

Laut memiliki komponen-komponen yang berpotensi mampu mengembalikan keadaan $\mathrm{pH}$ dan suhu secara alami. Beberapa komponen tersebut di antaranya adalah lamun, mangrove, dan alga yang memiliki peran sebagai penyerap $\mathrm{CO}_{2}$ di laut melalui mekanisme fotosintesis, sehingga dapat dikatakan bahwa komponen tersebut dapat mengurangi pengasaman laut. Namun, yang perlu ditinjau adalah seberapa besarkah peran komponen tersebut dalam mengatasi pengasaman laut dan bagaimana sebenarnya peran komponen tersebut sehingga dapat mengurangi terjadinya pengasaman laut secara alami? Penelitian ini akan memberikan gambaran dan kajian mengenai peranan komponen penyusun ekosisistem pesisir seperti mangrove, lamun dan alga dalam menjalankan langkah mitigasi alami untuk pengasaman laut.

\section{METODE PENELITIAN}

Penelitian ini menggunakan metode studi literatur dengan mengkaji beberapa artikel terkait. Artikel-artikel yang ditelusuri adalah yang memuat data mengenai kemampuan komponen beberapa penyusun ekosistem pesisir untuk dapat mengatasi pengasaman laut.

\section{HASIL DAN PEMBAHASAN}

Pengasaman laut terjadi karena menurunnya $\mathrm{pH}$ air laut akibat meningkatnya kadar karbon anorganik di laut. Laut dapat mengembalikan keadaannya seperti semula menggunakan larutan buffering yang secara alamiah terbentuk lewat siklus biogeokimia yang terjadi di dalam laut. Sistem buffering ini bekerja dengan cara mengendalikan alkalinitas di laut. Alkalinitas merupakan kemampuan laut secara alami untuk menstabilkan $\mathrm{pH}$ laut yang terlalu asam dengan larutan penyangga alami (Trick dkk., 2018).

Terdapat beberapa mekanisme untuk meningkatkan alkalinitas seperti proses fotosintesis dan juga presipitasi karbonat. Fotosintesis merupakan proses yang terjadi pada tanaman yang menggunakan $\mathrm{CO}_{2}$ untuk membuat makanan untuk tanaman itu sendiri. Pada akhirnya proses fotosintesis ini akan menyimpan unsur karbon melalui mekanisme siklus karbon dalam ekosistem. Sehingga mengurangi potensi terbentuknya $\mathrm{CO}_{2}$ berlebih di atmosfer. Presipitasi karbonat merupakan proses untuk mencegah terbentuknya karbon anorganik dengan cara mereaksikan ion karbonat dengan ion kalsium untuk membentuk kalsium karbonat. Kedua mekanisme ini dapat mempengaruhi kemampuan laut untuk menaikan $\mathrm{pH}$.

Beberapa komponen di ekosistem pesisir memiliki kemampuan untuk meningkatkan alkalinitas melalui jalur fotosintesis dan presipitasi karbonat seperti lamun, mangrove, dan alga.

\section{Lamun}

Lamun merupakan salah satu dari 3 komponen penyusun ekosistem pantai. Lamun ialah tanaman air yang berbunga (Antophyta) dan mempunyai kemampuan beradaptasi untuk hidup dan tumbuh di lingkungan laut (Azkab 2006). Lamun memiliki peran penting di lingkungan, yaitu sebagai habitat dari beberapa hewan laut dan juga sebagai sumber makanan beberapa hewan laut seperti dugong dan juga penyu. Selain itu, lamun memiliki peran terhadap ekosistem yaitu mengurangi pengasaman laut. 
Asam yang terkandung dalam air dapat menurunkan nilai saturasi aragonit yang mana jika nilainya di bawah 1 , maka karang dan kerang akan mudah rusak. Senyawa Argonit inilah yang dijadikan sebagai indikator pengasaman laut. Padang lamun memiliki potensi untuk meningkatkan saturasi aragonit hingga 2,9 unit, dan $\mathrm{pH}$ sebesar 0,38. Hal tersebut setidaknya akan memberi peningkatan pertumbuhan karang sekitar $18 \%$, sehingga lamun dapat dijadikan sebagai alat potensial bagi pengelola taman laut (Unsworth dkk., 2012).

Yates, K. dkk (2016) juga mengatakan bahwa lamun mampu meningkatkan $\mathrm{pH}$ air laut dan keadaan saturasi mineral karbonat melalui fotosintesis, dan dapat membantu melindungi terhadap dampak kimia dari pengasaman laut.

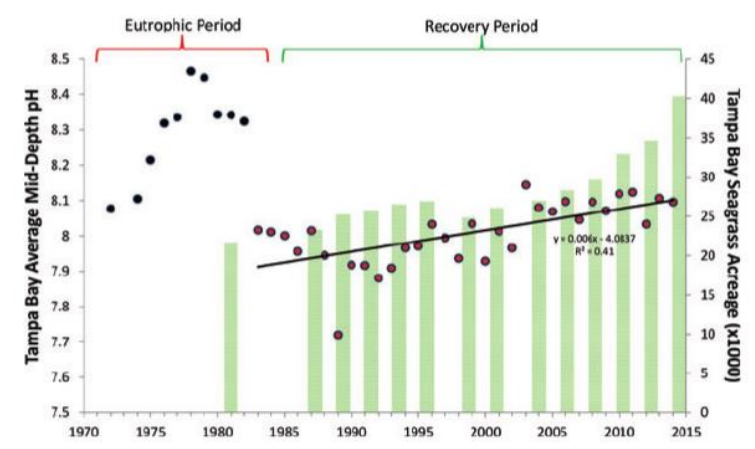

Table 1. Rata-rata $\mathrm{pH}$ dari pemantauan kualitas air di Tampa Bay relatif terhadap cakupan lamun (Sherwood dkk., 2017)

Data pemantauan kualitas air pada Tabel 1. menunjukkan bahwa $\mathrm{pH}$ air laut telah meningkat sejak tahun 1980-an karena padang lamun terus pulih sejak saat itu. Dengan demikian, dapat disimpulkan bahwa padang lamun dapat memberikan perlindungan bagi organisme laut dari dampak pengasaman laut.

\section{Alga}

Alga terbagi menjadi dua jenis, yaitu makroalga dan mirkoalga. Secara ekologis, komunitas makroalga mempunyai peranan dan manfaat terhadap lingkungan sekitarnya yaitu sebagai tempat asuhan dan perlindungan bagi jenis-jenis ikan tertentu (nursery grounds), tempat pemijahan (spawning grounds), sebagai tempat mencari makanan alami ikan-ikan dan hewan herbivor (feeding grounds) (Miala, Pratomo, dan Irawan 2015). Sedangkan mikroalga lebih dikenal sebagai produsen dalam rantai makanan di laut.

Selain itu, makroalga juga dinilai dapat mengurangi pengasaman laut. Makroalga dapat berperan melalui mekanisme fotosintesis dan juga pengeluaran enzim yang dapat membantu memecah $\mathrm{CO}_{2}$ menjadi ion bikarbonat. Ketika Ion bikarbonat bereaksi dengan ion kalsium, maka dapat digunakan untuk proses kalsifikasi oleh alga itu sendiri, ataupun oleh karang, kerang dan hewan laut lain yang membutuhkan kalsium karbonat untuk membuat rangka tubuhnya (Scherner dkk., 2016).

Perpindahan ion bikarbonat dari air dapat mencegah $\mathrm{pH}$ laut menjadi turun. Beberapa alga dapat menggunakan bikarbonat tersebut untuk proses kalsifikasi seperti Halimeda cuneata. Semakin banyaknya Halimeda cuneate, maka akan menurunkan kemungkinan terjadinya pengasaman laut.

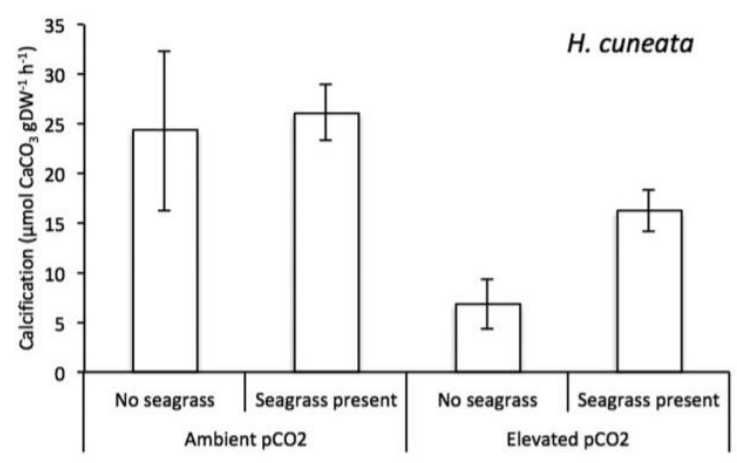

Table 2. Respon kalsifikasi rata-rata $H$. cuneata dengan ada atau tanpa lamun di sekitar lingkungannya (Bergstrom dkk., 2019)

Meskipun alga memiliki laju fotosintesis yang lebih rendah dibandingkan lamun, namun apabila dihadirkan secara bersamaan, seperti pada Tabel 2., terlihat bahwa lamun akan memberi efek positif pada kalsifikasi alga karena lamun akan berperan sebagai buffer terhadap pengasaman.

Hal ini terbukti dengan hasil penelitian yang telah dilakukan oleh Bergstorm, E. dkk. (2019), di mana kehadiran lamun $H$. wrightii mengurangi efek negatif pengasaman laut pada kalsifikasi alga $H$. cuneata, sehingga dapat dikatakan bahwa lamun masih mampu mempertahankan tingkat fotosintesis yang relatif tinggi di bawah konsentrasi $\mathrm{CO}_{2}$ yang tinggi, dan nantinya dapat menciptakan kondisi air laut yang kondusif untuk kalsifikasi alga. 


\section{Mangrove}

Ekosistem mangrove merupakan ekosistem yang mempertemukan area daratan dan lautan. Ekosistem ini memiliki fungsi yang sangat krusial menyangkut daratan dan lautan, di antaranya yaitu mencegah abrasi, pengendalian interupsi air laut ke daratan, mengurangi dampak angin ke daratan, tempat berlindung sebagian besar hewan laut yang masih kecil dan juga tempat pemijahan alami dan yang terakhir mangrove dapat mengurangi polusi yang ada di lautan (Kusmana 2009).

Mangrove dapat melindungi laut dari terjadinya pengasaman laut karena dapat meningkatkan alkalinitas perairan di sekitar ekosistem. Alkalinitas adalah kemampuan laut secara alami untuk menstabilkan $\mathrm{pH}$ laut yang terlalu asam dengan larutan penyangga alami (Trick, Stuart, dan Reeder, 2018). Kemampuan inilah yang dapat melawan pengasaman.

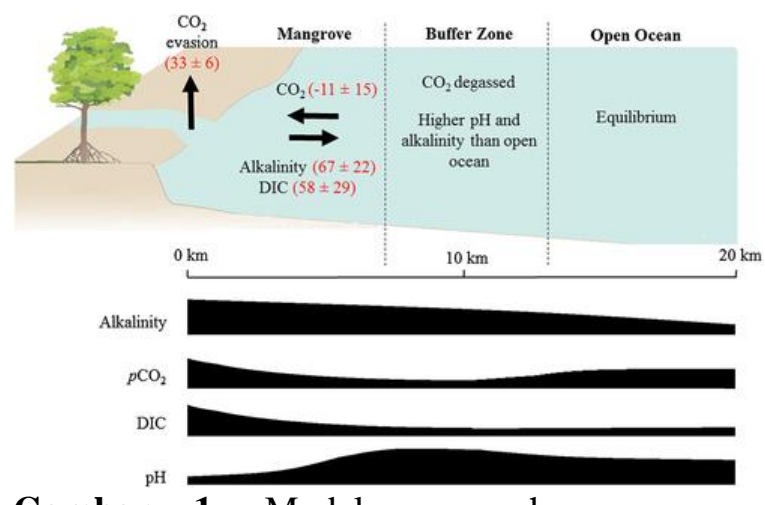

Gambar 1. Model pengaruh mangrove terhadap pertukaran karbon di pesisir laut dalam satuan $\mathrm{mmol} \mathrm{m}^{-2} \mathrm{~d}^{-1}$. (Sippo et al. 2016)

Pada penelitian yang dilakukan oleh Sippo, J. Z. dkk. (2016), mereka meneliti pengaruh keberadaan mangrove dalam mengatasi pengasaman laut lewat produksi senyawa alkaline, didapatkan hasil bahwa mekanisme pertukaran karbon dari atmosfer ke laut ataupun sebaliknya akan meningkatkan produksi senyawa alkaline yang tinggi di wilayah tersebut. Senyawa alkaline yang terbentuk, akan terdistribusikan ke laut lepas lewat peranan ombak dan arus dan menciptakan suatu zona penyangga. Adanya zona penyangga ini akan meningkatkan $\mathrm{pH}$ di laut dan diharapkan dapat mengurangi pengasaman laut secara alami.

Para peneliti menyiratkan bahwa peningkatan $\mathrm{pH}$ dari mangrove ini dapat memiliki efek yang lebih besar di daerah dengan cakupan bakau yang besar, dan dapat berdampak pada ekosistem pesisir tropis lainnya seperti terumbu karang (Cyronak dkk.. 2018). Selain itu, dari hasil peneltian tersebut dapat diketahui bahwa mangrove merupakan salah satu sumber alkalinitas alami terbesar untuk lautan pesisir tropis.

\section{PENUTUP}

Komponen penyusun pesisir dapat menjadi pilar penting untuk mengatasi pengasaman laut secara alami. Namun dalam hal ini komponen seperti lamun, mangrove dan alga tidak bisa dalam waktu sekejap mengatasi pengasaman laut yang kian lama semakin memburuk. Oleh karena itu perlu peran dari masyarakat untuk secara sadar ikut menjaga laut dan melestarikan komponen-komponen yang ada sehingga keadaan laut tidak semakin memburuk.

\section{DAFTAR PUSTAKA}

Azkab, Muhamad Husni. 2006. "Ada Apa Dengan Lamun." Oseana 31 (3): 45-55.

Bergstrom, Ellie, João Silva, Cíntia Martins, and Paulo Horta. 2019. "Seagrass Can Mitigate Negative Ocean Acidification Effects on Calcifying Algae." Scientific Reports 9 (1): $1-11$. https://doi.org/10.1038/s41598-01835670-3.

"Biological Impact of Ocean Acidification." n.d. BIOACID. https://www.oceanacidification.de/oceanacidification/?lang=en.

Cyronak, Tyler, Andreas J. Andersson, Sydney D'Angelo, Philip Bresnahan, Charles Davidson, Alyssa Griffin, Theodor Kindeberg, Jimmy Pennise, Yuichiro Takeshita, and Margot White. 2018. "Short-Term Spatial and Temporal Carbonate Chemistry Variability in Two Contrasting Seagrass Meadows: Implications for $\mathrm{PH}$ Buffering Capacities." Estuaries and Coasts 41 (5): 1282-96. https://doi.org/10.1007/s12237017-0356-5.

Kusmana, Cecep. 2009. "Pengelolaan Sistem Mangrove Secara Terpadu." Workshop on Mangrove Ecosystems Management in West Java, 1-22. 
Martono. 2012. "Fenomena Gas Rumah Kaca." Forum Teknologi 5 (2): 78-82.

Miala, I., A. Pratomo, and H. Irawan. 2015. "Hubungan Antara Bulu Babi, Makroalgae Dan Karang Di Perairan Daerah Pulau Pucung." Repository UMRAH 5 (January).

Pandolfi, John M., Sean R. Connolly, Dustin J. Marshall, and Anne L. Cohen. 2011. "Projecting Coral Reef Futures under Global Warming and Ocean Acidification." Science 333 (6041): 418 22.

https://doi.org/10.1126/science.1204794.

Quéré, Corinne Le, Robbie M. Andrew, Pierre Friedlingstein, Stephen Sitch, Julia Pongratz, Andrew C. Manning, Jan Ivar Korsbakken, et al. 2018. "Global Carbon Budget 2018 (Pre-Print)." Earth System Science Data Discussions pre print (November): $\quad 1-54$. https://doi.org/10.5194/essd-2017-123.

Scherner, Fernando, Cristiano Macedo Pereira, Gustavo Duarte, Paulo Antunes Horta, Clovis Barreira E Castro, José Bonomi Barufi, and Sonia Maria Barreto Pereira. 2016. "Effects of Ocean Acidification and Temperature Increases on the Photosynthesis of Tropical Reef Calcified Macroalgae." PLoS ONE 11 (5): 1-14. https://doi.org/10.1371/journal.pone.0154 844.

Sherwood, Edward T., Holly S. Greening, J. O.Roger Johansson, Kristen Kaufman, and Gary E. Raulerson. 2017. "Tampa Bay (Florida, USA): Documenting Seagrass Recovery since the 1980's and Reviewing the Benefits." Southeastern Geographer $57 \quad$ (3): 294-319. https://doi.org/10.1353/sgo.2017.0026.

Sippo, James Z, Damien T Maher, Douglas R Tait, Ceylena Holloway, and Isaac $R$ Santos. 2016. "Are Mangrove Drivers or Buffers of Coastal Acidification?" Global Biogeochemical Cycles, no. Dic: 753-66. https://doi.org/10.1002/2015GB005324.R eceived.

Trick, Julian K., Marianne Stuart, and Shaun Reeder. $2018 . \quad$ Contaminated Groundwater Sampling and Quality Control of Water Analyses. Environmental Geochemistry: Site Characterization, Data Analysis and Case Histories: Second Edition. 2nd ed. Elsevier B.V.
https://doi.org/10.1016/B978-0-44463763-5.00004-5.

Unsworth, Richard K.F., Catherine J. Collier, Gideon M. Henderson, and Len J. McKenzie. 2012. "Tropical Seagrass Meadows Modify Seawater Carbon Chemistry: Implications for Coral Reefs Impacted by Ocean Acidification." Environmental Research Letters 7 (2). https://doi.org/10.1088/17489326/7/2/024026.

World Meteorological Organization. 2018. "Greenhouse Gas Levels in Atmosphere Reach New Record." World Meteorological Organization. 2018. https://public.wmo.int/en/media/pressrelease/greenhouse-gas-levelsatmosphere-reach-newrecord\#: :text=The WMO Greenhouse Gas Bulletin,and 400.1 ppm in 2015.\&text=The WMO Greenhouse Gas Bulletin reports on atmospheric concentrations of greenhouse gases. 